\title{
ANALISIS DAN PERANCANGAN DESAIN GRAFIS INFORMASI UNTUK PENINGKATAN KUALITAS INFORMASI PADA LAPORAN OPERASIONAL OUTSTANDING ORGANIZER DI SURABAYA
}

\author{
Christian Alvin Anggriawan \\ Akuntansi / Fakultas Bisnis dan Ekonomika \\ christianalvinanggriawan@gmail.com
}

\begin{abstract}
Abstrak
Grafis informasi adalah representatif visual dari sebuah informasi atau data yang disampaikan melalui sebuah grafik atau gambar yang menarik. Grafis informasi menjadi cara yang efektif untuk mengubah informasi yang rumit atau membingungkan menjadi lebih sederhana, mudah dipahami dan lebih menarik untuk dilihat. Dengan cara yang lebih kreatif dalam sistem informasi akuntansi, akan membuat penyajian informasi menjadi lebih memiliki kualitas informasi.

Kualitas informasi yang baik tentu diinginkan oleh perusahaan.Oleh karena itu Outstanding Organizer dapat menggunakan grafis informasi dalam menyajikan informasi.Dengan grafis informasi yang diterapkan dalam Outstanding Organizer, pihak yang berkepentingan terhadap informasi dapat mengetahui dan memahami informasi penting dalam laporan operasional Outstanding Organizer dengan lebih tepat.Sehingga keputusan yang diambil untuk periode berikutnya dapat membawa Outstanding Organizer menjadi lebih baik.

Cara penyajian informasi dengan grafis informasi sangat efisien dan efektif sehingga dapat meningkatkan kualitas informasi perusahaan.

Kata Kunci :Grafis informasi, Sistem informasi akuntansi, Kualitas informasi, Event organizer

\section{Pendahuluan}

Perkembangan dunia usaha mengalami persaingan yang sangat ketat dalam segala bidang baik barang maupun jasa.Persaingan tersebut jelas karena kemajuan suatu perekonomian negara dan tidak terlepas dari teknologi yang menentukan secara tidak langsung, para pesaing dengan kreatifitasnya masing-masing mengembangkan
\end{abstract}


aneka ragam produk barang maupun jasa dengan kualitas yang cukup terpercaya dan dapat diakui kehebatannya.

Badan Pusat Statistik (BPS) nasional pada tahun 2012 mendapatkan data bahwa di Indonesia ada 55.530.000 UMKM dan 54.000.000 diantaranya adalah usaha mikro. Perhitungan Deputi Bidang Pengkajian Kemenkop dan UKM berdasarkan data dan kriteria yang ditetapkan oleh BPS ditemukan ada peningkatan jumlah wirausahawan sebesar 1,56\%.

Perusahaan event organizer di Indonesia khususnya surabaya telah berkembang pesat walaupun tidak semua dikenal oleh masyarakat Indonesia, setidaknya perusahaan tersebut dikenal di daerah asal. Meningkatnya jumlah perusahaan event organizer mengakibatkan persaingan menjadi lebih ketat.Berdasarkan data yang terdapat pada Yellow Pages 2014, Perusahaan event organizer di Indonesia saat ini sudah sebanyak 613 perusahaan.Sedangkan untuk di Surabaya sebanyak 44 perusahaan event organizer.Kompetensi dari pada setiap perusahaan event organizer yang berbeda satu sama lain dapat menentukan keberhasilan perusahaan dalam memenangkan persaingan. Perusahaan yang mempunyai kompetensi terbaik akan mampu bertahan hidup di dunia yang kompetitif, yang paling penting adalah perusahaan harus mampu mengetahui kompetensi yang dimilikinya. Perusahaan membutuhkan sistem informasi yang baik dalam operasional perusahaan agar dapat tercapai tujuan perusahaan.

Untuk mencapai suatu tujuan, perusahaan harus mempunyai sebuah strategi penyampaian sistem informasi yang efektif. Efektivitas sistem informasi merupakan upaya organisasi untuk memanfaatkan kemampuan dan potensi sistem informasi yang dimiliki untuk mencapai tujuan (Simatupang dan Akib, 2007)

Gupta et al (2007), menyatakan bahwa sistem informasi mempunyai hubungan positif signifikan terhadap efektivitas sistem informasi. Informasi yang semakin berkualitas akan membuat menjadi lebih efisien. Sistem informasi 
menawarkan sinergi dan efisiensi informasi pada suatu organisasi(Dewett dan Jones, 2001)

Lingkungan sekitar kita semakin berkembang. Perkembangan metode penyampaian informasi telah mengubah cara kita berpikir dan berkomunikasi. Mencari dan menyampaikan informasi menjadi lebih mudah dengan metode atau media tertentu yang menarik dan mudah dipahami.Informasi perlu dikonsumsi dan diproses dengan metode-metode yang harus diperbaharui.Grafis informasi adalah salah satu metode baru dalam menyampaikan informasi.Komunikasi lebih baik mengandalkan metode visualisasi.Grafis Informasi merupakan visualisasi informasi yang memungkinkan kita mendapatkan wawasan dan memahami dengan cepat dan efisien, dengan memanfaatkan kemampuan pengolahan sistem visual manusia.Grafis informasi sangat diperlukan saat kita berhadapan dengan begitu banyak data atau informasi yang dihadirkan kepada kita setiap hari.

Grafis informasi mulai terlihat popularitasnya sejak tahun 2004.Hal ini terlihat dari Google “Insights for Search" yang menganalisis meningkatnya penggunaan kata kunci grafis informasi sejak tahun 2004.

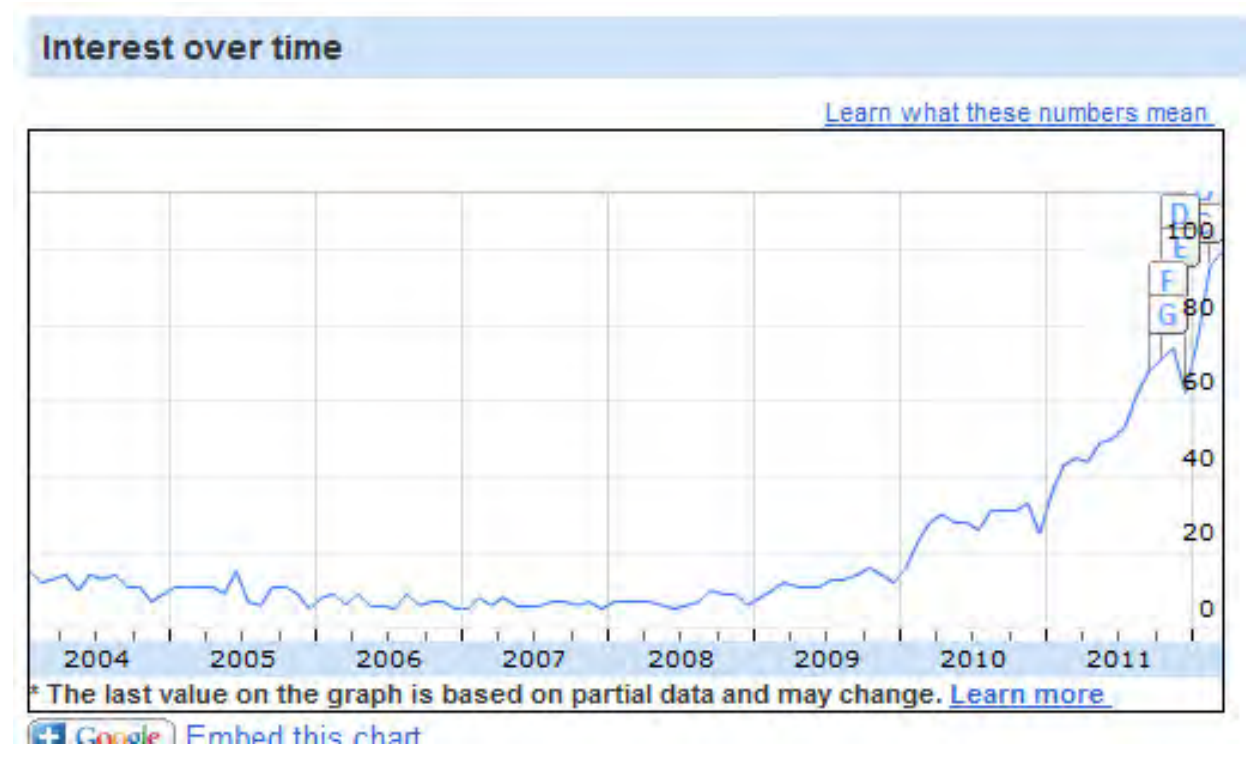

Grafik 1 
Peningkatan penggunaan kata kunci grafis informasi sejak tahun 2004 (Sumber: Jeffbullas, 2012)
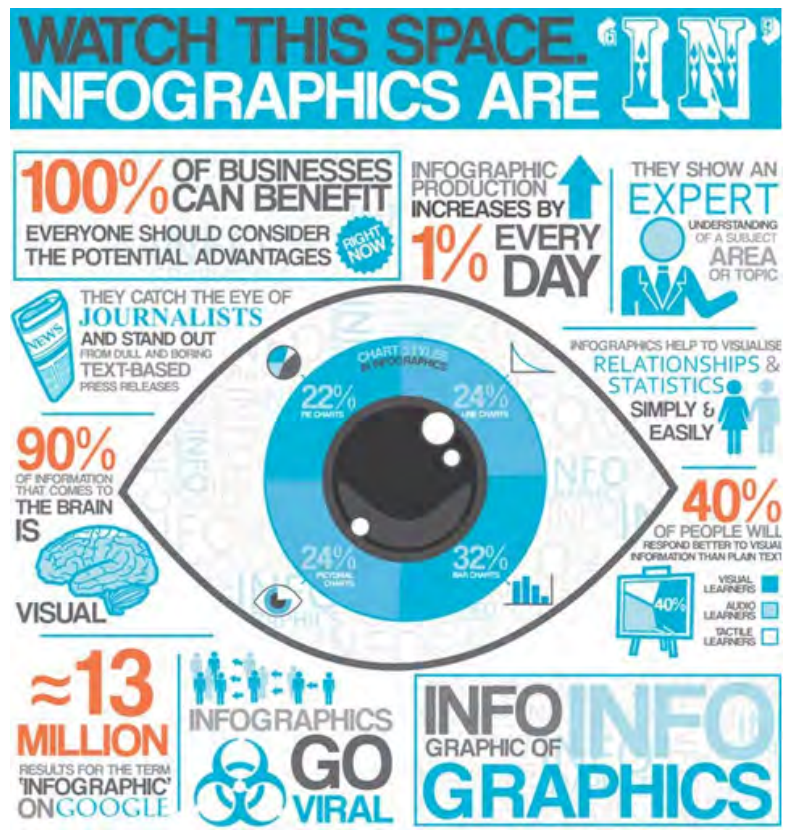

\section{Gambar 1}

Grafis informasi

(Sumber: Jeffbullas, 2012) 


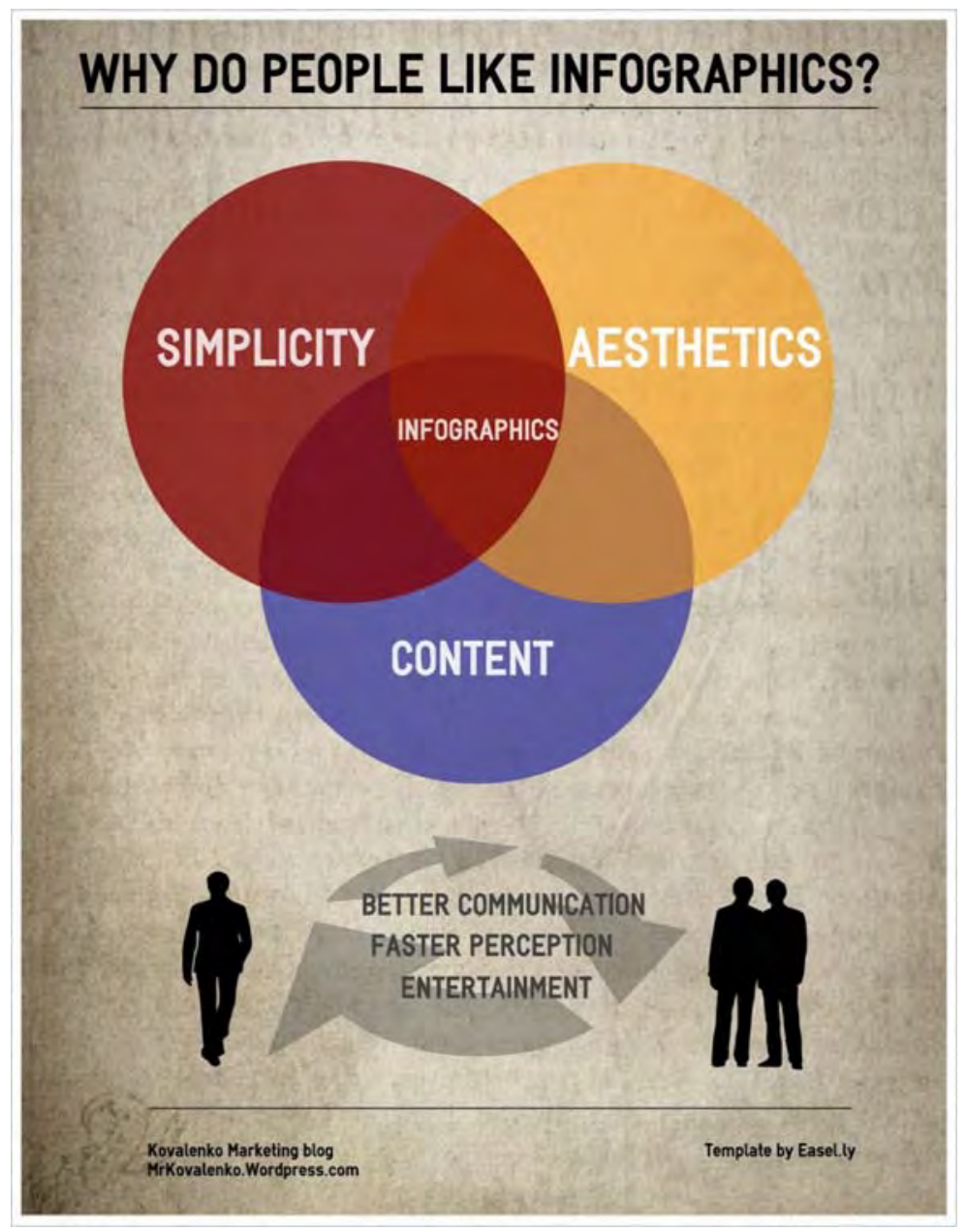

\section{Gambar 2}

\section{Alasan penting orang menyukai grafis informasi}

(Sumber: kovalenko, 2013)

Hal di atas merupakan hal penting yang harus diterapkan dan diperhatikan oleh perusahaan.Penggunaan grafis informasi pada Outstanding Organizer sangat penting karena grafis informasi merupakan salah satu faktor untuk dapat meningkatkan kualitas informasi yang disajikan. Tidak adanya sistem informasi yang mudah dipahami seperti grafis informasi maka perusahaan tersebut tidak akan mudah untuk meningkatkan kualitas informasi. Dengan penerapan grafis informasi diharapkan dapat memberikan informasi yang mudah dipahami dan diterapkan 
dengan tetap memperhatikan standar perancangan informasi yaitu terdapat kekuatan, kegunaan dan keindahan.

Penelitian ini dilakukan untuk membantu Outstanding Organizer dalam meningkatkan kualitas informasi sebagai perusahaan startup.Rancangan grafis informasi yang tercipta dari penelitian ini diharapkan dapat diterapkan oleh Outstanding Organizer dan bahkan bisa menjadi kelebihan yang membedakan Outstanding Organizer dengan perusahaan sejenislain.

\section{Metode Penelitian}

Penelitian ini menggunakan penelitian kualitatif dengan tujuan penelitian Explanatory Research, yang bertujuan untuk mengembangkan dan meningkatkan pemahaman tentang penerapan grafis informasi dan merancang sistem grafis informasi untuk Outstanding Organizer. Berdasarkan manfaat studinya, penelitian ini menggunakan applied research (penelitian terapan) karena penelitian ini dilakukan untuk memecahkan masalah yang ada dalam perusahaan yaitu masalah sistem informasi akuntansi yang tidak memiliki kualitas informasi. Berdasarkan penelitiannya, penelitian yang dilakukan adalah field study (penelitian lapangan) karena dilakukan pada aktivitas kerja sehari-hari.

Metode pengumpulan data yang digunakan adalah wawancara, observasi dan analisis dokumen.Untuk menjawab mini research question yang pertama, dilakukan wawancara kepada manajemen Outstanding Organizer.Observasi dilakukan pada rapat yang diadakan oleh masing-masing bagian.Analisis dokumen dilakukan pada laporan operasional perusahaan yang tidak menggunakan grafis informasi.Untuk menjawab mini research question yang kedua, dengan analisis lebih mendalam dari hasil yang didapatkan.Untuk menjawab mini research question yang ketiga dilakukan wawancara pada manajemen dan klien perusahaan.Observasi dilaksanakan pada rapat pada masing-masing bagian.Analisis dokumen dilakukan pada dokumen perusahaan terkait dengan sistem informasi akuntansi, laporan operasional dan Hasil Wawancara serta Observasi. 


\section{Hasil dan Pembahasan}

Informasi yang disajikan akan menentukan keputusan para pengambil keputusan dalam rapat inti tahunan. Laporan Operasional Oustanding Organizer dibuat oleh manajer umum.Jangka waktu pembuatan laporan operasional adalah sekali dalam setahun.Laporan Operasional yang dibuat oleh manajer umum tidak mudah untuk dipahami karena banyaknya tulisan dan tabel. Hal ini dipertegas oleh Yulius Liutama sebagai koordinator acara Outstanding Organizer yang mengatakan “Tulisan yang banyak membuat pembacanya tidak dapat fokus dan menemukan informasi penting didalamnya, apalagi banyak tabel antara satu tabel dengan tabel yang lain tidak jelas”. Informasi harus dibuat sejelas mungkin agar dapat dipahami dengan baik oleh pembaca.

Penerapan laporan operasional perusahaan sudah berjalan sejak tahun 2012, tetapi saat tahun 2012 tidak terdapat LKKB, hanya laporan laba rugi yang ada pada laporan operasional. Hal ini dikarenakan Outstanding Organizer masih dalam masa perintisan dan belum terdapat sistem yang baik dalam pengolahan informasi.LKKB baru muncul saat januari tahun 2013.Keputusan dibuatnya LKKB bukanlah keputusan bersama melainkan keputusan yang diambil secara sepihak oleh direktur.Keputusan ini diambil karena kesadaran bahwa sangat penting untuk menciptakan suatu sistem informasi yang lengkap bukan hanya keuangan saja melalui laporan laba rugi perusahaan. LKKB memang tidak mudah untuk dipahami, hal ini dipertegas dengan apa yang dikatakan oleh Ang Suk Cen sebagai konsultan manajemen Oustanding Organizer yaitu “LKKB yang mulai dilaksanakan pada tahun 2013 terlalu prematur karena belum sepenuhnya bermanfaat bagi manajemen. Terlalu banyak penjelasan yang tidak penting dan membuat pembaca menjadi malas untuk membaca”.Berdasarkan pendapat manajemen dan analisis dokumen yang dilakukan oleh peneliti, penjelasan yang tidak penting itu adalah penjeleasan yang cenderung diulang-ulang dan terkesan pembuatnya ingin menegaskan kepada pembaca mengenai informasi yang didapatkan. Penegasan dalam bentuk tulisan akan membuat tulisan menjadi lebih banyak dan bagi pembaca dapat mengakibatkan kebosanan. 
Format laporan operasional perusahaan harus diadakan perubahan yang lebih efisien dan efektif.Format laporan operasional sejak awal tahun 2013 telah ditetapkan oleh direktur dan manajer umum sebagai pembuatnya hanya mengikuti format awal yang telah ditetapkan oleh direktur.Direktur yang mempunyai hak untuk melakukan perubahan pada format laporan operasional perusahaan.

Informasi yang disajikan dalam laporan operasional Outstanding Organizer adalah

- LKKB

- Informasi konsep acara atau tema yang paling disukai oleh klien.

- Informasi aktivitas karyawan selama setahun.

- Informasi acara yang paling banyak diadakan.

- $\quad$ Informasi laporan laba rugi

Sistem informasi menawarkan sinergi dan efisiensi informasi pada suatu organisasi.Efisiensi informasi harus dapat dirasakan oleh penggunanya, bukan membuat kebingungan kepada penggunanya. Kebingungan dalam membaca akan membuat waktu untuk memahami informasi juga menjadi lebih lama dan belum tentu maksud yang dipahami tersebut benar.

Informasi yang kurang dapat dipahami dengan baik jelas dikarenakan kualitas informasi yang buruk, maka perusahaan harus mencari solusi terbaik dalam menyelesaikan masalah tersebut.Grafis informasi dapat menjadi solusi untuk menyelesaikan masalah yang terjadi. Dengan grafis informasi, pembaca informasi akan dapat lebih memahami dan saat menciptakan keputusan menjadi lebih efektif untuk Outstanding Organizer di masa mendatang.

Kesulitan dalam memahami informasi menjadi kesulitan utama, selain itu kesulitan untuk menyediakan waktu lebih banyak saat membaca informasi.Aktivitas 
padat yang dialami oleh para pimpinan membuat informasi yang butuh waktu lebih lama untuk dipahami menjadi tidak sepenuhnya dipahami.

Grafis informasi lebih cocok digunakan pada penyajian informasi laporan operasional dikarenakan grafis informasi memberikan singkatan yang sangat praktis dan tidak perlu membuang waktu yang panjang untuk memahaminya.Simbol-simbol pada grafis informasi dapat mewakili satu kalimat bahkan paragraf.Grafis informasi dapat memudahkan pembaca informasi dalam memahami informasi yang disajikan.

Kualitas informasi juga akan semakin meningkat karena salah satu karakteristik pentingnya yaitu mudah dipahami, dapat direalisasikan dengan baik dengan bantuan grafis informasi. Grafis informasi dapat meningkatkan kualitas informasi pada laporan operasional Outstanding Organizer.

Tidak ada pengukuran yang jelas terhadap informasi yang disajikan. Pengukuran tidak jelas akan mengakibatkan kualitas informasi menjadi buruk. Hal ini terlihat dari laporan operasional yang disajikan tidak menunjukan tolak ukur yang digunakan secara pasti dapat dijadikan dasar.

Sebagai Contoh adalah penilaian terhadap karyawan tidak menunjukan bahwa karyawan dinilai dengan tolak ukur yang jelas, penilain hanya berdasarkan penilaian subjektif dari direktur.Sebaiknya terdapat tolak ukur yang jelas dan tertulis serta disepakati bersama. Karyawan harus mengetahui bagaimana cara dan kriteria penilaian yang dilakukan kepadanya, agar apa yang dilakukannya dapat sesuai dengan apa yang diharapkan oleh perusahaan.

Tolak ukur yang tidak dapat dijelaskan dengan baik dan objektif akan membuat kesalahan penggunaan informasi dan berdampak negative pada perusahaan. Karyawan tidak jelas arah dan tujuannya, mereka hanya bekerja sebaik mungkin tanpa arah dan tujuan yang jelas. Karyawan juga tidak akan tahu kapan ia dapat nilai baik dan kapan dia dapat nilai buruk. Penilaian semacam ini sangatlah tidak adil dan tidak berkualitas. Hal ini didukung oleh Ricky Surya sebagai koordinator pemasaran 
Outstanding Organizer mengatakan "tim pemasaran seringkali kecewa dan merasa tidak dihargai dengan adil”

Selain penilaian aktivitas karyawan yang membutuhkan tolak ukur yang jelas, ketiga laporan di dalam laporan operasional juga membutuhkan tolak ukur yang jelas.Laporan tren konsep atau tema tahun 2014 selain menggunakan perhitungan akumulasi permintaan konsep atau tema, juga menyertakan perhitungan biaya paling efisien.Laporan jenis acara yang paling sering diadakan tahun 2014 selain menggunakan perhitungan akumulasi permintaan acara tertentu, juga menyertakan jumlah profit yang didapat. Hal yang perlu untuk diperhatikan agar tidak terjadi adalah jangan sampai saat disajikan acara perusahaan memang banyak dipilih oleh klien, tetapi karena tidak melihat dari segi pendapatan ternyata sama saja pendapatannya antara acara perusahaan yang banyak dan acara pernikahan yang sedikit. Sehingga jika pimpinan mengubah arah fokus perusahaan pada acara perusahaan ternyata membuat perusahaan semakin tidak efisien. Laporan laba rugi sebaiknya bukan hanya menunjukan grafik laba bersih tahun sebelum-sebelumnya tetapi juga secara interaktif dapat menunjukan laba bersih tahun depan yang belum terjadi dengan melakukan prediksi serta perkiraan oleh manajemen.

Ang suk cen sebagai konsultan manajemen Outstanding Organizer mengatakan "Penyampaian informasi secara visual yang bukan hanya menarik perhatian tetapi juga logis pasti akan lebih mudah untuk diterima dan dipahami”.Berdasarkan kebutuhan untuk mengatasi kesulitan dan kelemahan tersebut.Grafis informasi menjadi solusi terbaik yang dapat digunakan dalam penyajian informasi laporan operasional dengan sangat efisien dan efektif.

Isyarat visual digunakan untuk melakukan komunikasi informasi dengan grafis informasi.Sistem informasi akuntansi pada Outstanding Organizer membutuhkan grafis informasi dalam penyajiannya.Grafis informasi untuk menyajikan laporan operasional.Laporan Operasional Outstanding Organizer sebelumnya penyajian informasi kurang berkualitas sehingga terjadi banyak 
permasalahan dalam penggunaannya.Efektif bagi penyajian laporan operasional Outstanding Organizer karena dapat menyampaikan informasi yang akurat sebagai dasar pengambilan keputusan.Efisien karena tidak perlu mengandung banyak jumlah data, kompleksitas informasi, dan tingkat analisis tertentu.

Grafis informasi dapat menyelesaikan masalah yang sedang dihadapi Outstanding Organizer. Permasalahan penyajian laporan operasional Outstanding Organizer diselesaikan dengan mengubah cara penyajian yang lama menjadi grafis informasi.

Grafis informasi yang tepat digunakan oleh Outstanding Organizer memiliki dua pendekatan perancangan yaitu eksploratif dan naratif. Pendekatan Eksploratif memiliki karakteristik minimalis, hanya mencakup elemen yang mewakili data, dan mencoba melakukan komunikasi informasi dengan cara yang paling jelas dan lengkap. Eksploratif cenderung mendorong pembaca menggali dan mengekstrasi wawasannya sendiri.Pendekatan Naratif memiliki karakteristik ilustratif, berfokus pada desain, mencoba menarik perhatian secara visual, informatif serta menghibur.Dalam pendekatan naratif terdapat unsur dekoratif yang dapat membantu retensi informasi yang disajikan.

Pendekatan Naratif merupakan pendekatan yang direkomendasikan pada Outstanding Organizer dalam penyajian informasi yang berbentuk grafis informasi karena definisi pendekatan naratif yang berfokus pada desain, mencoba menarik perhatian secara visual, informatif serta menghibur sesuai dengan apa yang dibutuhkan Outstanding Organizer. Hal ini sama dengan pendapat Ang Suk Cen sebagai Konsultan Manajemen Perusahaan “Event organizer adalah perusahaan dekat dengan seni kreatif, maka perlu cara yang kreatif dan menarik untuk menyelesaikan masalah”. Permasalahan Outstanding Organizer mengenai penyajian informasi pada laporan operasional yang kualitas informasinya rendah dapat diselesaikan dengan grafis informasi yang memiliki pendekatan naratif.

Grafis informasi yang tepat digunakan dalam sistem informasi akuntansi Outstanding Organizer bukan hanya menggunakan pendekatan naratif, tetapi juga 
harus sesuai dengan hakikat visualisasi informasi yang benar. Visualisasi informasi menjadi bentuk grafis informasi merupakan proses menjadikan visual suatu pengetahuan meliputi visualisasi data atau sekedar isyarat visual untuk menggambarkan, membedakan, atau menunjukkan hierarki dalam informasi.

Bentuk data yang divisualisasikan yaitu seperti diagram lingkaran, diagram batang, diagram garis, dan sebagainya. Edward sebagai presiden direktur PT Kakakberadik Plaza yang menjadi klien Outstanding Organizer mengatakan bahwa "Isi informasi yang dijelaskan oleh tim pemasaran sudah bagus karena sangat kompleks dan detail. Data dari informasi tersebut telah mendukung informasi yang disampaikan, tetapi tim pemasaran tidak dapat melakukan penyampaian atau penyajian informasi dengan baik, tim pemasaran hanya bercerita dengan herbal tanpa penggambaran dengan fisik yang dapat dilihat secara visual. Lebih mudah memahami informasi dengan penggambaran secara visual yang unik dan kreatif” Hubungan dalam setiap data sangatlah kompleks, hal ini yang menjadi alasan dilakukannya visualisasi data secara unik dan kreatif untuk lebih mudah dibaca dan dipahami.

Sistem informasi akuntansi tujuan utamanya adalah dibuat untuk membantu perusahaan dalam mencapai tujuannya. Tujuan perusahaan akan tercapai dengan menemukan dan menggunakan cara yang tepat. Cara tersebut dapat mendukung atau memberikan bantuan kepada perusahaan untuk lebih efektif dan efisien dalam mencapai tujuannya.

Visualisasi data Outstanding Organizer pada sistem informasi akuntansi dilakukan dengan grafis informasi yang membantu perusahaan agar dalam penyajian dapat dengan mudah dipahami secara efektif dan efisien.Grafis informasi yang digunakan harus memiliki kekuatan, kegunaan dan keindahan dalam perancangan.

Kekuatan grafis informasi pada Oustanding Organizer terletak pada data yang digunakan berserta bagaimana grafis informasi tersebut sangat diperlukan.Hal ini jelas menunjukan kekuatan grafis informasi yang dapat menentukan peningkatan kualitas informasi Oustanding Organizer. Ricky Surya sebagai koordinator pemasaran Ouststanding Organizer mengatakan "kekuatan sistem informasi yang dapat menentukan tim pemasaran, tim acara dan klien akan dapat memahami dengan baik 
informasi yang disajikan dan memberikan dampak positif pada perusahaan. Pengguna informasi dapat memahami dengan baik jika ada metode penyampaian yang kreatif” Permasalahan dalam menunjukan kekuatan informasi dapat diselesaikan dengan penerapan grafis informasi pada sistem informasi akuntansi Ouststanding Organizer.Grafis informasi adalah metode penyampaian yang bukan hanya kreatif tetapi juga unik.

Kegunaan grafis informasi adalah menjadi solusi terbaik dalam permasalahaan penyampaian informasi yang buruk pada laporan operasional Outstanding Organizer.Hal ini diteguhkan oleh Yulius Liutama sebagai koordinator acara Oustanding Organizer yang mengatakan "Informasi yang disajikan dengan karya seni sangat unik dan dapat diterima dengan baik oleh otak, manifestasinya adalah pemahaman yang efektif secara mudah dan efisien secara cepat tanpa waktu yang panjang untuk memahaminya.Jelas hal ini sangat berguna bagi perusahaan”.Grafis informasi tidak selalu memberikan dampak yang baik, karena harus disesuaikan dengan kondisi kebutuhan perusahaan.Perusahaan yang masih konservatif cenderung tidak dapat menerima model penyajian informasi menggunakan grafis informasi. Perusahaan konservatif lebih nyaman dengan menggunakan cara lama yang menggunakan tulisan dan tabel yang banyak tanpa ilustrasi sedikitpun. Dalam perusahaan konservatif, grafis informasi menjadi tidak berguna. Lain halnya dengan grafis informasi yang diterapkan pada perusahaan startup atau modern seperti Oustanding Organizer ditambah bidang usahanya yang bergerak di industri kreatif maka akan sangat berguna. Manusia pada dasarnya menyukai hal yang unik dan kreatif dengan perbedaan warna yang bagus dan menarik.

Keindahan dalam grafis informasi menjadi salah satu bagian terpenting. Grafis informasi yang tidak diikuti dengan keindahan akan sama halnya dengan tanpa menggunakan grafis informasi. Keindahan membantu manusia menjadi lebih tenang dan dapat mencerna segala informasi yang disajikan dengan baik.Grafis informasi harus disertai dengan keindahan dalam penyajiannya. Ricky Surya sebagai koordinator pemasaran memberikan peneguhan bahwa "Karyawan cukup stres dengan apa yang dikerjakan setiap hari, sebagai contoh tim pemasaran yang selalu 
dikejar target pendapatan dan tim acara yang dikejar dateline dari timeline yang telah ditentukan sejak awal. Hal yang kreatif dan menyenangkan adalah hal yang dapat mendukung mood karyawan untuk menerima informasi” Keindahan sama halnya dengan hal yang menyenangkan. Manusia selalu membutuhkan hal yang menyenangkan. Kesenangan akan keindahan penyajian laporan operasional dapat dengan cepat memberikan dampak baik bagi Oustanding Organizer.

Grafis informasi bertujuan menyampaikan informasi yang berbeda satu dengan lainnya.Perbedaan tersebut dibedakan berdasarkan prioritas.Prioritas-prioritas ini berperan dalam menentukan perbedaan yang perlu dalam pendekatan untuk tiap rancangan.

Tiga prioritas untuk semua metode visual yang efektif, yaitu :

a. Daya Pikat

Komunikasi terjalin tanpa paksaan.

b. Komprehensi

Komunikasi mempunyai pengetahuan yang jelas.

c. Retensi

Komunikasi tidak mudah untuk dilupakan.

Penerapan grafis informasi pada laporan operasional Outstanding Organizer untuk dapat meningkatkan kualitas informasi lebih tepat menggunakan komunikasi informasi dengan cara yang sejelas mungkin dan tanpa bias sama sekali, maka prioritas pertama adalah komprehensi, kedua retensi dan ketiga daya pikat.

Grafis informasi memiliki tiga format penting yaitu statis, konten bergerak dan interaktif.Format yang dibutuhkan oleh Outstanding Organizer dalam penyelesaian masalah adalah grafis informasi format statis. Format statis bersifat tetap yang ditampilkan dengan citra diam. Interaksi pengguna informasi adalah melihat dan membaca. Format statis yang digunakan Outstanding Organizer sangat tepat jika menggunakan pendekatan naratif pada perancangan grafis informasi laporan operasional yaitu LKKB, sedangkan untuk laporan operasional laba rugi menggunakan format interaktif dengan pendekatan eksploratif. 
Kegunaan grafis informasi format interaktif adalah untuk menampilkan data yang banyak dan ingin menciptakan konten interaktif yang menarik pengguna melakukan eksplorasi lebih lanjut. Laporan laba rugi yang disajikan dengan grafis informasi diharapkan dapat memberikan informasi yang sangat jelas kepada pengguna serta penggunapun dapat melakukan perencanaan untuk tahun depan dalam meningkatkan laba bersih.

Kegunaan grafis informasi format statis adalah untuk menampilkan konten berumur panjang yang akan tetap relevan tanpa sering harus diperbaharui. Laporan operasional digunakan selama setahun kedepan dan akan terus diperbaharui setiap tahunnya. Penggunaan grafis informasi untuk menampilkan laporan operasional Outstanding Organizer adalah 1 tahun lamanya.Format statis sangat tepat untuk grafis informasi yang digunakan dalam penyajian laporan operasional Outstanding Organizer untuk meningkatkan kualitas informasi Outstanding Organizer.

Grafis informasi editorial tepat digunakan pada Outstanding Organizer.Penggunaan pendekatan naratif sangat tepat pada grafis informasi editorial.Konten grafis informasi editorial tidak merunjuk kepada kepentingan perusahaan seperti menunjukkan logo perusahaan.Logo perusahaan diletakkan dibagian bawah.Grafis informasi editorial menjawab kebutuhan penyajian informasi pada Outstanding Organizer.Informasi laporan operasional Outstanding Organizer bukan bertujuan untuk promosi Outstanding Organizer, tetapi bertujuan untuk memberikan informasi kepada internal. 


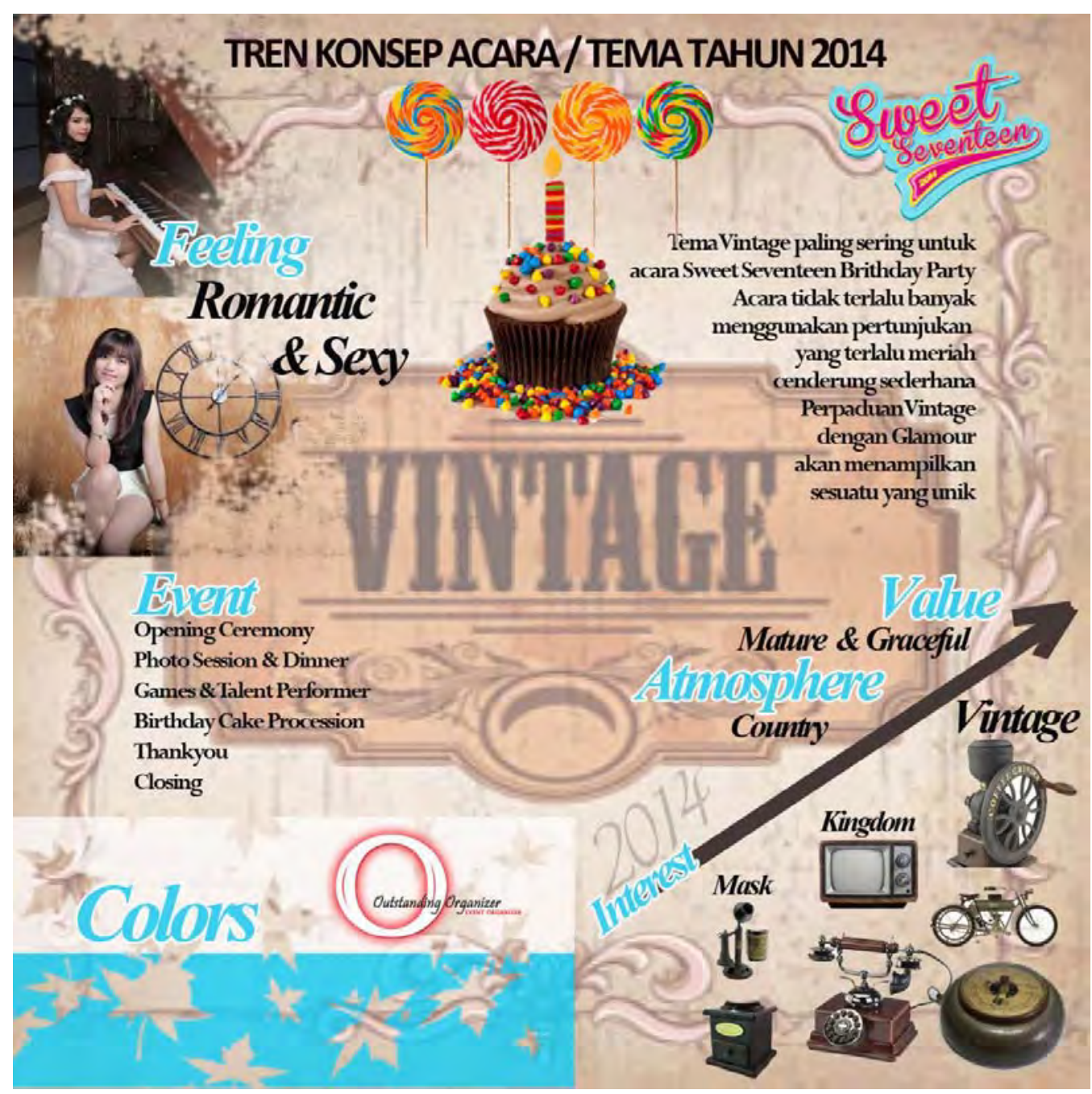

Gambar 3

Contoh Grafis Informasi Konsep Acara atau Tema yang Paling Disukai 


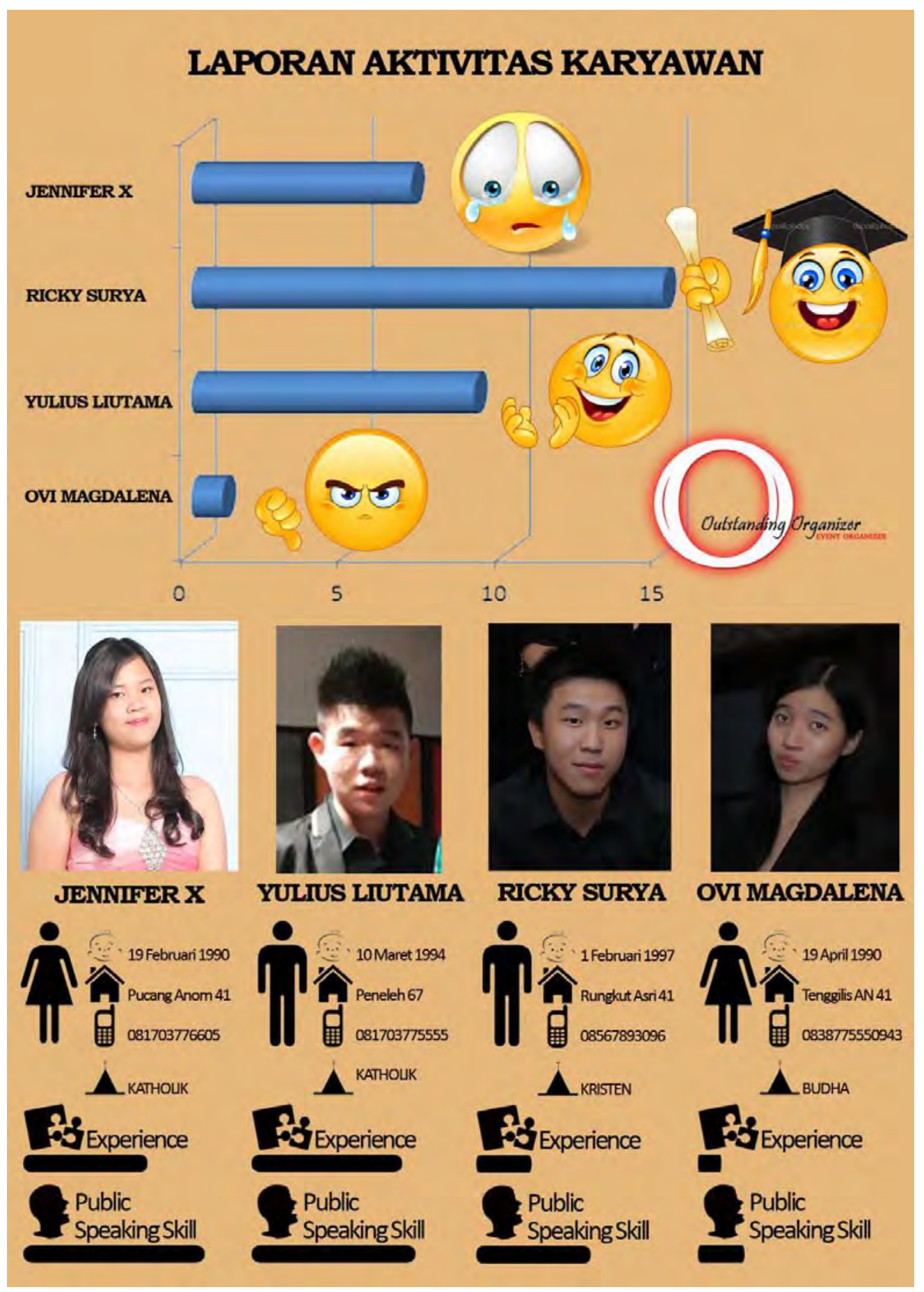

Gambar 4

Contoh Grafis Informasi Aktivitas Karyawan 


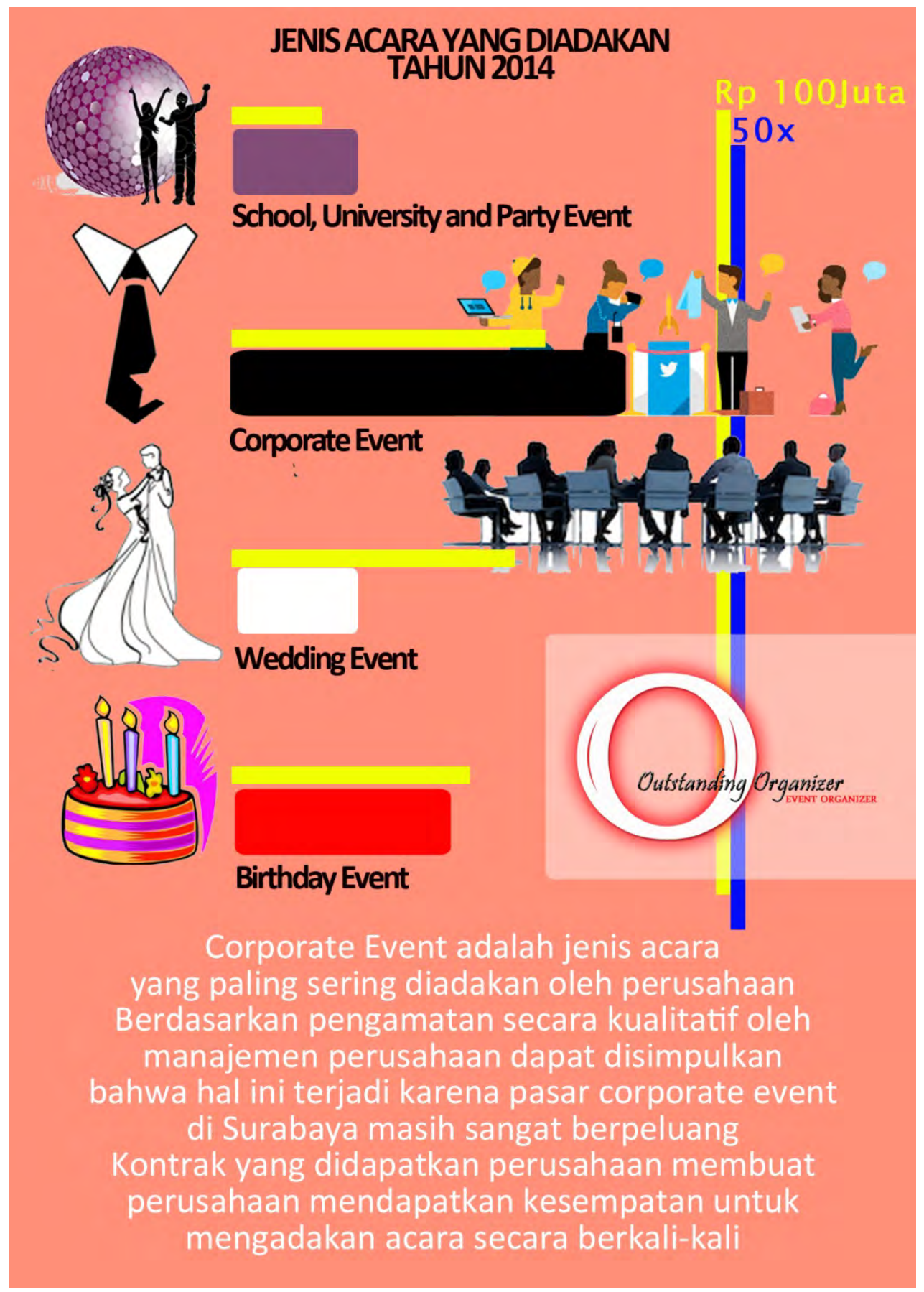

\section{Gambar 5}

Contoh Grafis Informasi Acara yang Paling Banyak Diadakan 


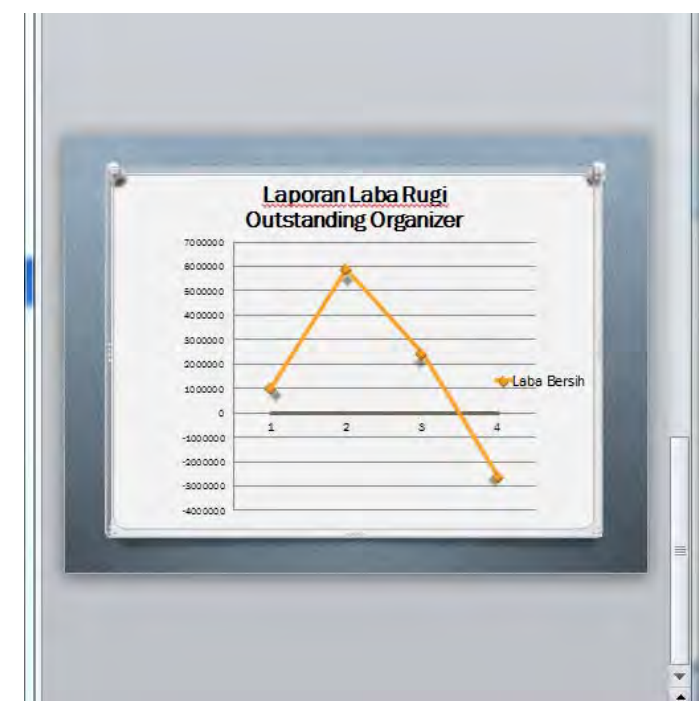

\begin{tabular}{|c|c|c|c|c|}
\hline 4 & $s$ & T & u & - \\
\hline 1 & Target Pendapatan & $42,500,000.00$ & & \\
\hline 2 & Beban & $45,100,000.00$ & & \\
\hline 3 & Laba Bersih & $(2,600,000.00)$ & & \\
\hline 4 & & & & \\
\hline 5 & Perencanaan Tahun Depan & & & \\
\hline 6 & & & & \\
\hline 7 & Kas & $\mathrm{Rp} 5,000,000$ & & \\
\hline 8 & Perlengkapan & $\mathrm{Rp} 3,000,000$ & & \\
\hline 9 & peralatan & Rp19,700,000 & & \\
\hline 10 & piutang & & & \\
\hline 11 & Ak Penyusutan Peralatan & & Rp8,016,667 & \\
\hline 12 & Utang Usaha & & $\mathrm{Rp} 8,000,000$ & \\
\hline 13 & Modal & & Rp14,283,333 & \\
\hline 14 & Prive & $\mathrm{RpO}$ & & \\
\hline 15 & Pendapatan Jasa & & Rp42,500,000 & \\
\hline 16 & Beban Gaji & $\operatorname{Rp} 36,000,000$ & & \\
\hline 17 & Beban Sewa & Rp3,000,000 & & \\
\hline 18 & Beban Iklan & $\mathrm{Rp} 500,000$ & & \\
\hline 19 & Beban lain-lain & $\mathrm{Rp} 3,000,000$ & & \\
\hline 20 & Beban Penyusutan Peralatan & $\mathrm{Rp} 2,600,000$ & & \\
\hline 21 & Utang Gaji & & $\mathrm{Rp0}$ & \\
\hline 22 & & Rp72,800,000 & Rp72,800,000 & \\
\hline
\end{tabular}

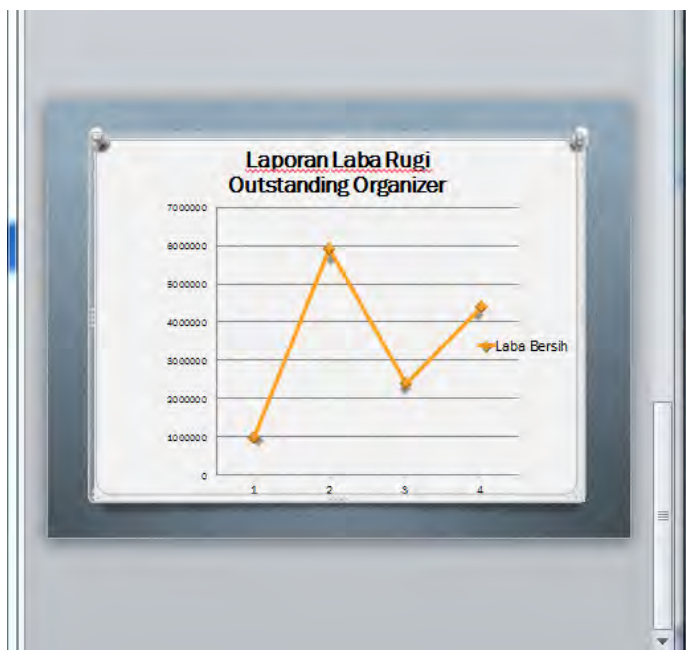

\begin{tabular}{|c|c|c|c|}
\hline 1 & Target Pendapatan & $49,500,000.00$ & \\
\hline 2 & Beban & $45,100,000.00$ & \\
\hline 3 & Laba Bersih & $4,400,000.00$ & \\
\hline 4 & & & \\
\hline 5 & Perencanaan Tahun Depan & & \\
\hline 6 & & & \\
\hline 7 & Kas & $\mathrm{Rp} 5,000,000$ & \\
\hline 8 & Perlengkapan & $\mathrm{Rp} 3,000,000$ & \\
\hline 9 & peralatan & Rp19,700,000 & \\
\hline 10 & piutang & & \\
\hline 11 & Ak Penyusutan Peralatan & & Rp8,016,667 \\
\hline 12 & Utang Usaha & & Rp1,000,000 \\
\hline 13 & Modal & & Rp14,283,333 \\
\hline 14 & Prive & Rp0 & \\
\hline 15 & Pendapatan Jasa & & Rp49,500,000 \\
\hline 16 & Beban Gaji & Rp36,000,000 & \\
\hline 17 & Beban Sewa & $\mathrm{Rp} 3,000,000$ & \\
\hline 18 & Beban Iklan & $\mathrm{Rp} 500,000$ & \\
\hline 19 & Beban lain-lain & $\mathrm{Rp} 3,000,000$ & \\
\hline 20 & Beban Penyusutan Peralatan & $\mathrm{Rp} 2,600,000$ & \\
\hline 21 & Utang Gaji & & $\mathrm{Rp0}$ \\
\hline 22 & & Rp72,800,000 & Rp72,800,000 \\
\hline
\end{tabular}

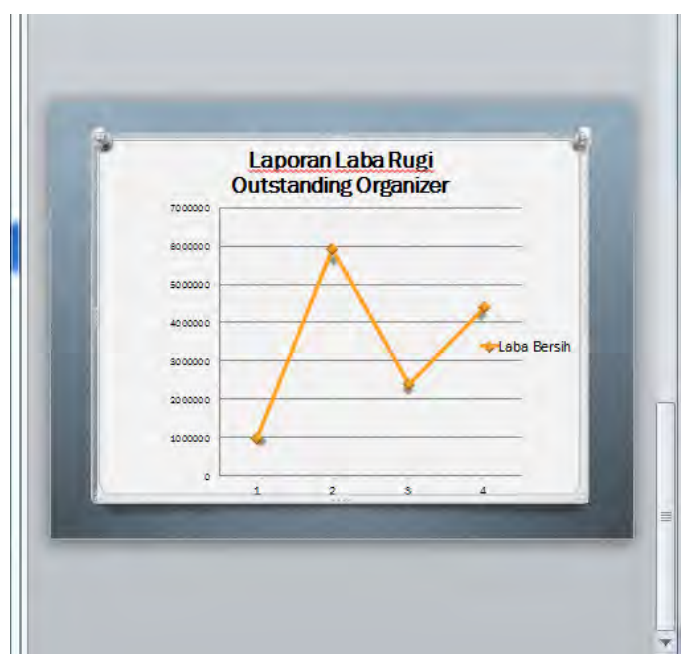

\begin{tabular}{|c|c|c|c|}
\hline 1 & Target Pendapatan & $49,500,000.00$ & \\
\hline 2 & Beban & $45,100,000.00$ & \\
\hline 3 & Laba Bersih & $4,400,000.00$ & \\
\hline 4 & & & \\
\hline 5 & Perencanaan Tahun Depan & & \\
\hline 6 & & & \\
\hline 7 & Kas & $\mathrm{Rp} 5,000,000$ & \\
\hline 8 & Perlengkapan & $\mathrm{Rp} 3,000,000$ & \\
\hline 9 & peralatan & Rp19,700,000 & \\
\hline 10 & piutang & & \\
\hline 11 & Ak Penyusutan Peralatan & & Rp8,016,667 \\
\hline 12 & Utang Usaha & & $\mathrm{Rp} 1,000,000$ \\
\hline 13 & Modal & & Rp14,283,333 \\
\hline 14 & Prive & $\mathrm{RpO}$ & \\
\hline 15 & Pendapatan Jasa & & Rp49,500,000 \\
\hline 16 & Beban Gaji & $\mathrm{Rp} 36,000,000$ & \\
\hline 17 & Beban Sewa & $\mathrm{Rp} 3,000,000$ & \\
\hline 18 & Beban Iklan & Rp500,000 & \\
\hline 19 & Beban lain-lain & $\mathrm{Rp} 3,000,000$ & \\
\hline 20 & Beban Penyusutan Peralatan & $\mathrm{Rp} 2,600,000$ & \\
\hline 21 & Utang Gaji & & $\mathrm{RpO}$ \\
\hline 22 & & Rp72,800,000 & Rp72,800,000 \\
\hline
\end{tabular}

\section{Gambar 6}




\section{Contoh Grafis Informasi Laporan Laba Rugi}

Desain grafis informasi yang efisien dan efektif untuk laporan operasional LKKB pada Outstanding Organizer adalah menggunakan grafis informasi editorial format statis dan menggunakan pendekatan naratif berkarakteristik ilustratif. Sedangkan untuk laporan operasional laba rugi pada Outstanding Organizer, grafis informasi yang digunakan adalah menggunakan grafis informasi editorial format interaktif dan menggunakan pendekatan ekploratif. Grafis informasi Outstanding Organizer harus memiliki kekuatan, kegunaan dan keindahan dalam perancangan. Komunikasi grafis informasi harus jelas dan tanpa bias sama sekali, maka muncul prioritas yang tepat untuk Outstanding Organizer adalah komprehensi, kedua retensi dan ketiga daya pikat.

Software yang dapat digunakan untuk membuat grafis informasi secara khusus hingasaat ini belum ada.Grafis informasi sebagian besar dibuat dengan menggunakan software photoshop.Penggunaan software photoshop tidaklah mudah, dibutuhkan kemampuan desain dan menguasai setiap alat pada photoshop.Maka agar kualitas informasi dapat tetapi tercipta dalam laporan operasional perusahaan.Maka penting untuk dilakukan pelatihan terhadap manajer umum yang memiliki peran penting dalam pembuatan laporan operasional.Tidak perlu mencari sumber daya manusia yang khusus memiliki kemampuan desain. Format dasar sebaiknya sudah dibuat sejak pelatihan sehingga setiap tahun, manajer umum hanya mengganti beberapa bagian dan hanya melakukan input data dengan mudah. Jika sudah terdapaat format dasar, maka bukan hal yang sulit untuk dilakukan pembuatan grafis informasi pada laporan operasional perusahaan setiap tahunnya.

\section{Kesimpulan dan Saran}

Berdasarkan hasil analisis dan perancangan pada bab-bab sebelumnya, maka dapat diambil kesimpulan bahwa :

1. Pengguna Informasi Akuntansi lebih ingin dapat memahami dengan cepat Meaning dan Justification, Bukan lagi Calculate dan Explain yang sangat kompleks dan membuang waktu 
2. Pemahaman pembaca terhadap informasi adalah hal yang sangat penting, karena informasi dapat menjadi pendukung tujuan diambilnya keputusan, dapat juga menghambat tujuan yang diinginkan dari keputusan jika informasi tidak dapat ditemukan informasi pentingnya.

3. Pembaca informasi cenderung jenuh dan tidak dapat fokus dengan banyaknya kata-kata yang terdapat pada informasi.

4. Informasi yang tidak dapat dipahami akan membuat penurunan kualitas informasi.

5. Kombinasi penggunaan bermacam-macam warna, gambar dan grafik yang disatukan dalam grafis informasi sangat membantu pembaca dalam mendapatkan hal penting dalam informasi.

6. Grafis Informasitepat digunakan dalam penyajian laporan operasional perusahaan karena dapat meningkatkan kualitas informasi.

7. Grafis Informasi yang digunakan dapat meningkatkan kemudahaan pengguna atau pembaca dalam memahami informasi pada laporan operasional perusahaan.

8. Grafis Informasi yang mudah dipahami berdampak positif pada keputusan atau kebijakan perusahaan yang lebih efektif dan tepat sasaran. 
Calyptra: Jurnal IImiah Mahasiswa Universitas Surabaya Vol.5 No.2 (2016)

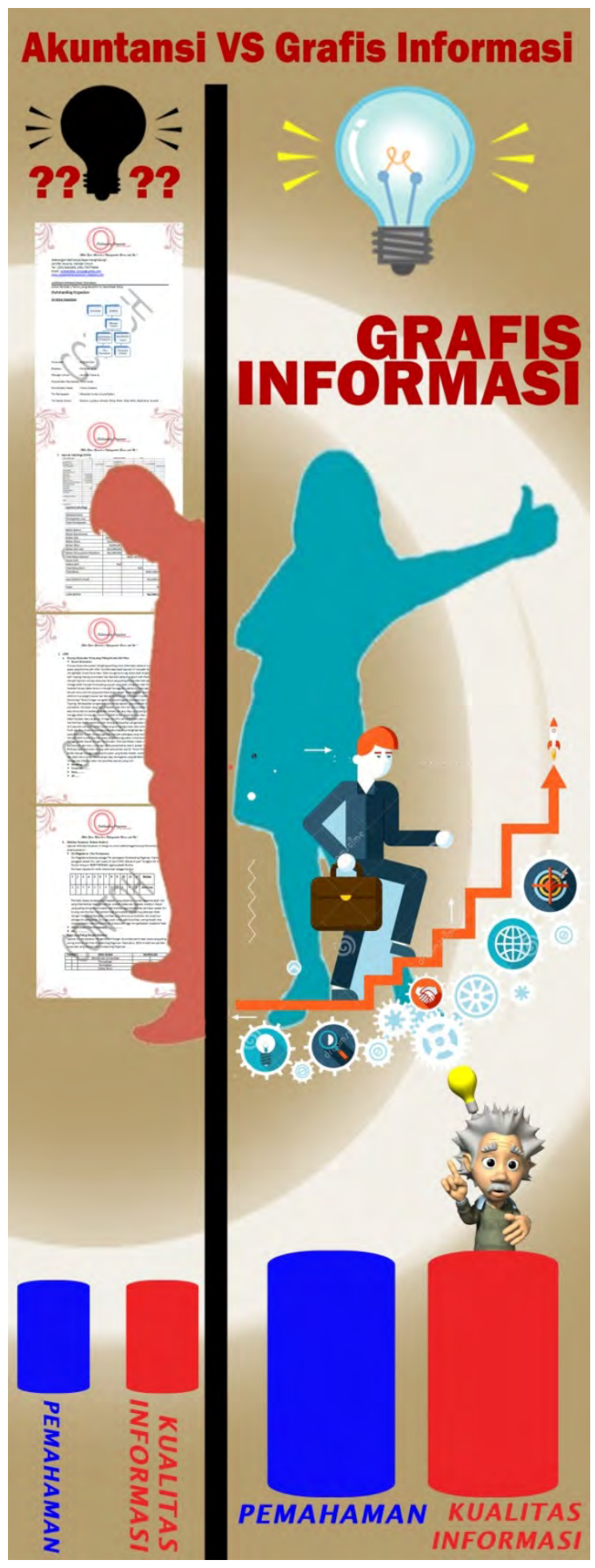

Gambar 7 


\section{Grafis Informasi Skripsi Analisis dan Perancangan Desain Grafis Informasi untuk Peningkatan Kualitas Informasi pada Laporan Operasional Outstanding Organizer di Surabaya}

Bagi Pembaca, sistem informasi yang disajikan secara menarik dapat memberikan informasi yang jelas. Apabila informasi yang disajikan sulit untuk dipahami, maka dapat dikatakan informasi tidak berkualitas akan dapat berdampak buruk pada keputusan yang diambil. Dunia bisnis yang selalu mengalami revolusi menjadi lebih modern membuat kita harus melakukan penyesuaian terhadap metodemetode yang digunakan dalam bisnis.Metode penyajian informasi menggunakan grafis informasi menjadi salah satu bentuk dari bisnis yang semakin modern. Dengan adanya perkembangan metode penyajian informasi menggunakan grafis informasi akan membuat informasi menjadi lebih mudah dipahami oleh pengguna informasi.

Perlu bagi pembaca memperlajari grafis informasi lebih luas dari sebelumnya untuk dapat menampilkan kualitas yang semakin baik dari informasi.

Bagi Perusahaan, metode penyampaian informasi menggunakan grafis informasi merupakan cara yang tepat untuk meningkatkan kualitas informasi pada perusahaan. Grafis informasi yang digunakan pada sistem informasi akuntansi lebih mudah dipahami oleh pembaca dibanding dengan penyampaian informasi yang penuh dengan tulisan dan tidak ada variasi warna. Kemudahan yang dialami oleh pembaca akan memberikan dampak yang baik pada operasional perusahaan.

Keputusan pimpinan juga menjadi lebih efektif sesuai dengan sasaran permasalahaan dan efisien karena tidak membutuhkan waktu yang lama dalam memahami mengenai apa yang terjadi dari informasi yang disajikan. Peningkatan kualitas informasi yang dapat ditimbulkan dari penggunaan metode grafis informasi menjadi rekomendasi kepada perusahaan untuk menggunakan metode penyampain informasi yang efektif dan efisien yaitu metode grafis informasi

\section{Daftar Pustaka}

Bodnar, George H, dan William S Hopwood. 2004. Sistem Informasi Akuntansi. Yogyakarta : Andi. 
Dewett, T. and Jones, G R. (2001). "The Role of IT in the Organization: A Review, Model, and Assessment”. Journal of Management”.Vol 27. No 3. pp: 313345.

Gupta M.P, Kanungo S, Kumar R dan Sahu G.P. 2007. "A Study of Information Technology Efectiveness in Select Governance Organizations in India.”Journal for Decision Makers.Vol 32.No. 2.

Gaol, Jimmy L. 2008. Sistem Informasi Manajemen. Jakarta: PT. Grasindo

Jason Lankow, Josh Ritchie, dan Ross Crooks. 2002. Infografis Kedasyatan Cara Bercerita Visual. Jakarta: PT.Gramedia Pustaka Utama

Kusrini, Andri Koniyo. 2007. Tuntunan Praktis Membangun Sistem Informasi Akuntansi Dengan Visual Basic dan Microsoft SQL Server. Yogyakarta: Andi

Mulyadi. 2001. Sistem Akuntansi. UGM.Yogyakarta : Salemba Empat.

O’brien, A, James. 2006. “Introduction To Information System.” Jakarta: Salemba Empat

Simatupang, Patar dan Akib, Haedar. 2007. Potret Efektivitas Organisasi Publik:Review Hasil Penelitian. Manajemen Usahawan Indonesia. No 01. Th.XXXVI.

Romney Marshal, Steinbart. 2004. Accounting Information System (Buku Satu). Jakarta: Salemba Empat.

Website : 
http://entrepreneur.bisnis.com/read/20120304/88/67018/jumlah-wirausaha-ri-naikjadi-1-56-percent(Diakses 28 November 2014)

http://www.jeffbullas.com/2012/03/07/9-awesome-reasons-to-use-infographics-inyour-content-marketing/(Diakses 1 November 2014)

http://kovalenkomarketing.com/2013/07/05/why-people-like-infographics/(Diakses 1 November 2014)

http://www.yellowpages.co.id/browse/category/event-organizer-

1?nameContains=event\%20organizer\&inCity=surabaya\&inCategory $=$ \&has Website $=$ \&hasEmail $=$ \&hasDisplay $\mathrm{Ad}=\&$ sortBy $=\&$ totalHits $=44 \&$ page $=3$ (Di akses 30 November 2014)

http://www.surakarta.go.id/konten/grafik-traffic-counting-masa-lebaran-2012-kotasurakarta-0(Diakses 4 November 2014)

http://junkcharts.typepad.com/junk_charts/dot_plot/page/5/(Diakses 5 November 2014)

http://junkcharts.typepad.com/junk_charts/dot_plot/page/5/ (Diakses 5 November 2014)

http://linksservice.com/diagram-garis/(Diakses 5 November 2014)

http://ariyanto.staff.uns.ac.id/2011/02/04/grafik-dengan-2-sumbu-vertikal-yangberbeda/(Diakses 5 November 2014)

http://winkonadi.wordpress.com/statistik-deskriptif/(Diakses 5 November 2014) 
http://willyakwila.blogspot.com/2013/07/statistika.html(Diakses 5 November 2014)

http://www.cara.aimyaya.com/2012/09/cara-membuat-diagram-piekue-di-msexcel.html(Diakses 5 November 2014)

http://www.presentasi.net/membuat-grafik-powerpoint-yang-efektif-danmenarik/(Diakses 5 November 2014)

http:/hr.blr.com/HR-news/Performance-Termination/Performance-EmployeeAppraisal/Infographic-2013-employee-performance-appraisal-pr\#(Diakses 1 Mei 2015) 